\title{
Impact of Tourism Industry on the Economic Growth of Sri Lanka
}

\author{
S. Anandasayanan (Corresponding author) \\ Senior Lecturer \\ Dept. of Financial Management, University of Jaffna, Sri Lanka \\ E-mail: sayananakshi@yahoo.com \\ S. Balagobei \\ Senior Lecturer \\ Dept. of Financial Management, University of Jaffna, Sri Lanka
}

M. Amaresh

Master of Business Administration, Faculty of Management Studies and Commerce University of Jaffna, Sri Lanka

Received: December 5, 2019

Accepted: January 17, 2020 Published: December 30, 2020

doi: 10.5296/ijafr.v10i4.15991

URL: https://doi.org/10.5296/ijafr.v10i4.15991

\begin{abstract}
In Sri Lanka, tourism has been identified as the third largest and fastest growing source of foreign currency in 2018, after private remittances and textile and garment exports, accounting for almost $\$ 4.4$ billion or 4.9 percent of gross domestic product in 2018 . Tourism industry is a key element which accelerates the economic growth by earning high foreign exchange and reducing poverty by providing direct and indirect employment opportunities to locals. This study primarily investigates the impact of between tourism sector on economic growth by employing Augmented Dickey Fuller's unit root test, correlation analysis and regression analysis. Annual data from 1989 to 2018 was used. The dependent variable was economic growth while tourists' receipts were independent variable. Strong and positive correlation was explored between tourists' receipts and economic growth meanwhile the results of regression analysis indicate that tourists' receipts significantly impact on the economic growth.
\end{abstract}




\section{Macrothink \\ International Journal of Accounting and Financial Reporting \\ ISSN 2162-3082 \\ 2020, Vol. 10, No. 4}

Keywords: Tourists receipts, Economic growth, Foreign exchange

\section{Introduction}

\subsection{Background of the Study}

Trade in services such as tourism, transport and computer services sector bring notable surplus to every country in the world as it increases foreign exchange income and employment opportunities. Tourism industry plays a significant role in promoting economic growth of developing countries. The number of international tourists exceeded 1 billion in 2012 and it is estimated that this number will go beyond 1.8 billion in 2030. Sri Lanka is a beautiful island which is located in the Indian ocean. It is an iconic country among world tourists for its fabulous tourist destinations like sand beaches, natural harbours, hills, mountains, forests, sanctuaries, ancient monuments, temples etc. Anuradhapura, Arugam Bay, Adam's Peak, Batticaloa, Bentota, Beruwala, Bundala National Park, Colombo, Dambulla, Ella, Galle, Hambantota, Hikkaduwa, Horton Plains, Jaffna, Kalkuda, Kandy, Katunayake, Kitulgala, Knuckles Range, Pasikuda, Pinnawela, Polanaruwa, Sigiriya, Trincomalee, Weligama, Wilpattu National Park and Yala National Park are some of the popular tourist attractions in Sri Lanka. Sri Lanka tourism sector is featured prominently with rapid growth but three decades of civil war between Sri Lankan government and Liberation Tigers of Tamil Eelam challenged tourism industry.The Sri Lankan government declared the end of the 26-year civil war between the Sri Lankan government and the Liberation Tigers of Tamil Eelam (LTTE) on $18^{\text {th }}$ of May, 2009. After the end of local war, the tourism industry started to flourish in Sri Lanka. Main purpose of this study is to find out the impact of tourism income on economic growth in Sri Lanka.

\subsection{Tourism and Economic Growth}

The contribution of tourism industry in economic growth has become an important factor. The tourism industry attracts Foreign Direct Investment (FDI) inflows which support sustained economic growth. As tourism has started to boom, Foreign Direct Investment inflows have also been rising. The tourism industry contributes to the economic growth and development is reflected in the form of exports since it represents 40 percent of all exports of services, making it one of the largest categories of international trade (UNWTO, 2006). According to the estimates of the World Tourism Organization (2000), the number of international people movements around the world will surge to 1602 million by 2020, while tourism receipts will reach some US $\$ 200$ billion. The enhancement in tourism industry led to a growth of household incomes and government revenues directly and indirectly by means of multiplier effects, improving balance of payments and provoking tourism promoted government policies. As a result, it is believed that the development of tourism brings a positive contribution to economic growth (Khan, Phang, \& Toh, 1995; Lee \& Kwon, 1995; Oh, 2005). Tourism industry reduces unemployment rate and poverty. 


\section{Ml Macrothink}

International Journal of Accounting and Financial Reporting

ISSN 2162-3082 2020, Vol. 10, No. 4

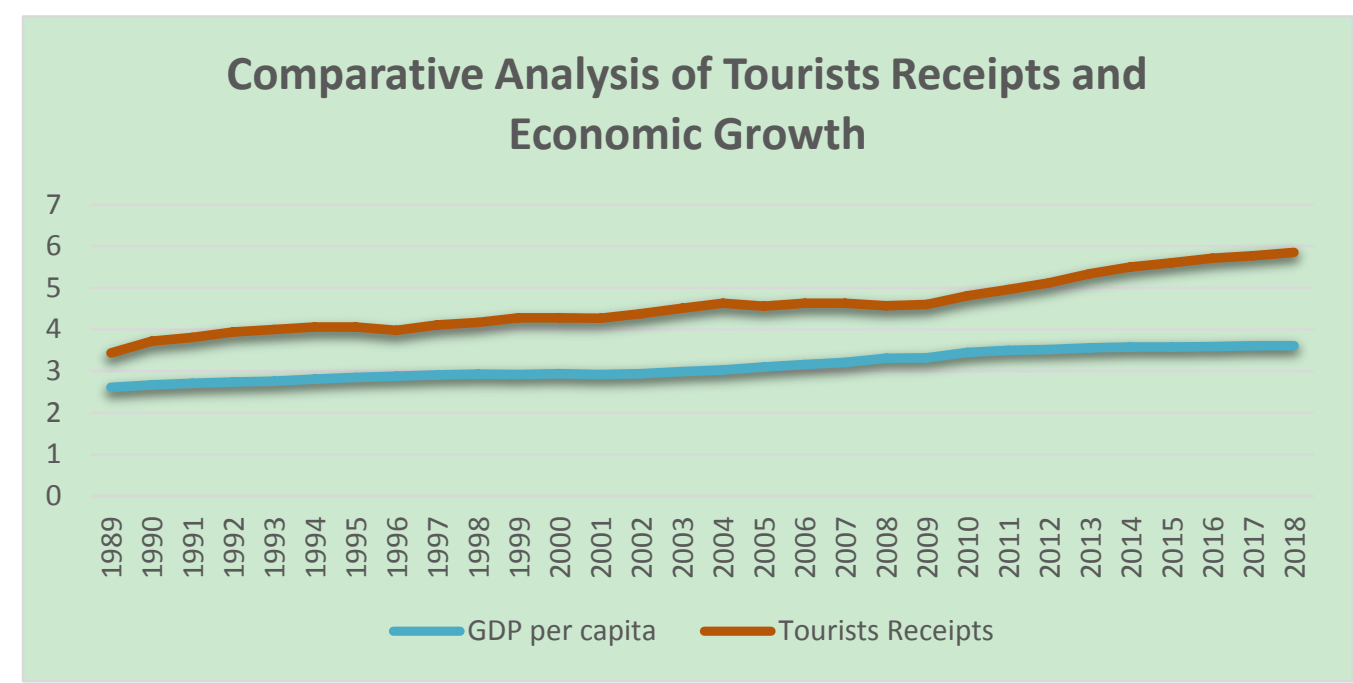

Figure 1. Comparative analysis of tourists receipts and economic growth

Figure 1 shows the wavy movement of tourism income and economic growth from 1989 to 2018. It is obvious that the tourism income is higher than the economic growth (GDP Per Capita).

\subsection{Research Problem}

As Sri Lankan tourism industry has been challenged by various factors, it is necessary to explore the relationship between tourism industry and economic growth. It is also important to identify to what extent tourism industry is affecting the economic growth. Further, contradiction in the findings of previous studies about the causality between tourism industry and economic growth. Some previous studies have found unidirectional causality from tourism to growth such as for Spain, Greece, Taiwan and Turkey. In contradiction, bidirectional causality was found between tourism and economic growth for China, non OECD and Mauritius. Some studies found no causality between tourism and economic growth such as for South Korea. Therefore, this study primarily intends to find out the exact causality between tourism and economic growth. Clarifying the relationship between tourism and economic growth would lead to improvement in earnings from tourism sector. This study will be beneficial for the responsible authorities to understand the necessity of tourism industry to economic growth, to increase the sustainability of the tourism sector and to carry out further enhancements to attract more tourists to Sri Lanka.

\subsection{The Objective of the Study}

The ultimate objective of the present study is to explore the impact tourism income on economic growth in Sri Lanka

\section{Literature Review}

Previously conducted studies that are related to tourism and economic growth are presented below. 


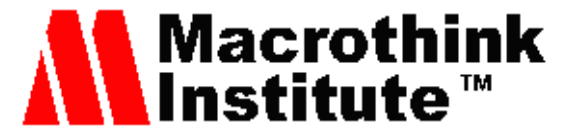

International Journal of Accounting and Financial Reporting

ISSN 2162-3082

2020, Vol. 10, No. 4

Yusuf, Cem \& Ibrahim (2009) examined the impact of tourism on economic growth in Turkey. Phillips-Perron test, Cointegration approach, Granger Causality test and a Vector Autoregression (VAR) model were employed in this study. The sampling period was from 1985 to 2007. The research findings indicated that tourism sector in Turkey is positively affected by the economic growth in the long run. It was also found that long run stable relationship between economic growth and tourism expansion.

Ding, Alan \& Pin (2016) carried out an investigation on tourism and economic growth. It examined whether international tourism promotes economic growth or if the effects of tourism development on economic growth work through the standard income determinants, instead. A tourism growth model was developed empirically that is an extension of Solow (1956) and estimate model with a cross-section of 109 countries. The research findings indicated that investments in tourism were insufficient for economic growth. Instead, tourism's contribution to the long-term growth of an economy comes through its role as an integral part of a broader development strategy that is more generally focused on standard income determinants.

Saroja (2007) examined the effect of war and other factors on Sri Lankan tourism. It attempted to identify the factors that affected tourist arrivals to Sri Lanka and the impact of the various disturbances due to the Tamils independence war and the introduction of the free-trade policy in Sri Lanka. The research findings revealed that the war had led to a significant (about 21\%) dwindle in international tourist arrivals to Sri Lanka. It was also found that the free-trade policy introduced in 1977 by the Sri Lankan government has had a significantly positive impact on increasing its international tourist arrivals. The findings also indicated that the weaker the value of the Sri Lankan local currency with respect to the US dollar, the more attractive it is for international tourists. Moreover, it was also explored that the Sri Lankan consumer prices and world consumer income level have no significant impact on the number of international tourist arrivals to Sri Lanka.

David, Fulbright, Marinko \& Jasmina (2004) examined the impact of war on tourism of Croatia. Several articles have examined the impact of war on tourism. Regression model was employed to examine the economic cost of war on Croatia due to the decline in tourism industry. The study used dummy variable approach to derive two regression equations for the war period and the pre/post war periods. The change in GDP caused by the change in tourism revenues can be derived from the coefficient of tourism revenues in the war equation. The research findings indicated that the economic impact of the decline in tourism was approximately US\$ 5B over the period of the war.

Fayissa, Nsiah and Tadasse (2007) carried out a research on the impact of tourism on economic growth and development in Africa by employing a panel data of 42 African countries for the years that span from 1995 to 2004. This investigation attempted to explore the potential contribution of tourism to economic growth and development within the conventional neoclassical framework. The research findings showed that receipts from the tourism industry significantly contribute both to the current level of gross domestic product and the economic growth of Sub-Saharan African countries as do investments in physical and human capital. 


\section{MInstitute ${ }^{\text {Mink }}$}

International Journal of Accounting and Financial Reporting

ISSN 2162-3082

Further, the study recommended that African economies could enhance their short-run economic growth by strategically strengthening their tourism industries.

Govdeli and Baskonus explored the long term relationship between tourism revenues and economic growth between 1977 and 2012 for OECD countries by employing panel cointegration test. Pedroni and Kao cointegration tests were used. The results of the panel cointegration analyses found that the increase of tourism revenues had a positive effect on economic growth in the long term.Dritsakis, (2012) examined the effect of tourist arrivals per capita, real effective exchange rate and real GDP per capita on GDP for 7 Mediterranean countries Spain, France, Italy, Greece, Turkey, Cyprus and Tunisia. The sampling period was from 1998 and 2011. Panel cointegration and fully modified ordinary least squares (FMOLS) were employed in this study. The findings explored that there was relationship between tourism and economic growth in 7 Mediterranean countries.

\section{Research Methodology}

\subsection{Data Collection and Sampling Method}

Secondary data collection is the primary data collection method employed in this study. The sampling period was from 1989 to 2018. 30 annual observations have been used in this research. The data of tourist's receipts has been collected from website of Sri Lanka Tourism Development Authority (SLTDA) website. The data of GDP Per Capita has taken from annual reports of central Bank of Sri Lanka. The dependent variable is economic growth (GDP Per capita) mean while tourism (tourists' receipts in million rupees) is the independent variable. Log values of both variables were taken for getting more accurate results.

\subsection{Conceptual Framework}

After reviewing the literature, the following conceptual model is formulated to examine the impact of tourism on economic growth.

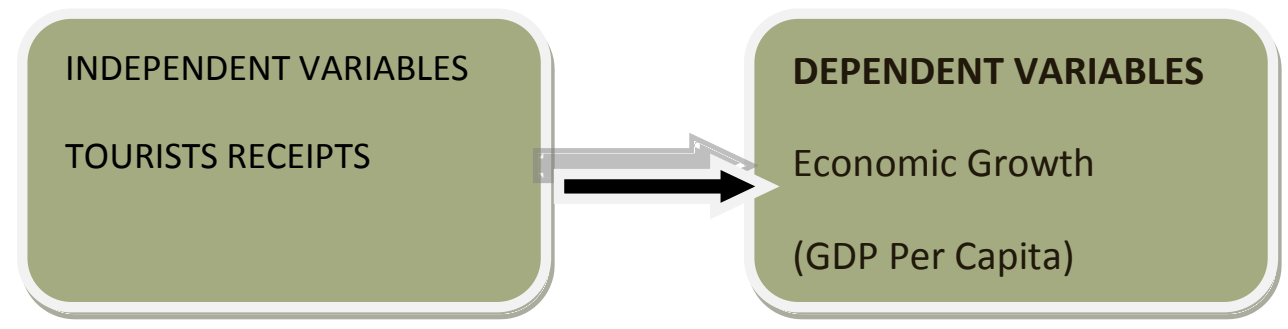

Figure 2. Conceptual Model

Source: Developed by researchers

The tourists' receipts in Million rupees is considered as the independent variable and economic growth (GDP per capita) is considered as the dependent variable.

\subsection{Definition of Variables}

Tourists Receipts 


\section{MlMacrothink}

International Journal of Accounting and Financial Reporting

ISSN 2162-3082

Tourist's receipts are expenditures that are made by visitors in the destination country. Tourists' receipts are used to measure the tourism income. It is given in million rupees.

Economic Growth

Economic growth is the increase in the amount of goods and services produced per head of the population during a period of time. GDP per capita is used to measure the economic growth in this study.

\subsection{Hypotheses of the Study}

Based on the conceptual model the following hypotheses are formulated.

$\mathbf{H}_{1}$ : Tourism income significantly impact on economic growth in Sri Lanka

\section{Results and Discussion}

\subsection{Descriptive Statistics}

The basic components of both dependent and independent variables are explained by descriptive statistics. It includes mean, maximum, minimum, standard deviation, skewness and kurtosis. The features of tourism and economic growth are presented in table no 1.

Table 1. Results of descriptive statistics

$\begin{array}{lrr} & \text { GDP PER } . . & \text { TOURISTS. } \\ \text { Mean } & 3.124243 & 4.578806 \\ \text { Median } & 3.009934 & 4.538418 \\ \text { Maximum } & 3.613274 & 5.852497 \\ \text { Minimum } & 2.611140 & 3.437703 \\ \text { Std. Dev. } & 0.332854 & 0.650768 \\ \text { Skewness } & 0.242644 & 0.513344 \\ \text { Kurtosis } & 1.616378 & 2.356975 \\ & & \\ \text { Jarque-Bera } & 2.687392 & 1.834461 \\ \text { Probability } & 0.260880 & 0.399624 \\ & & \\ \text { Sum } & 93.72730 & 137.3642 \\ \text { Sum Sq. Dev. } & 3.212959 & 12.28145 \\ & & \\ \text { Observations } & 30 & 30\end{array}$

The Table 1 clearly represents the descriptive statistics of both independent and dependent variables. 30 annual observations from 1989 to 2018 have been included in the study. The mean of GDP per capita is 3.124243, 3.613274 is the maximum, 2.611140 is the minimum, 0.332854 is standard deviation, 0.242644 is skewness, and 1.616378 is the kurtosis meanwhile the mean, maximum, minimum, standard deviation, skewness and kurtosis of tourists receipts are $4.578806,5.852497,3.437703,0.650768,0.513344$ and 2.356975 respectively.

\subsection{Correlation Analysis}

The correlation analysis is carried out to explore the relationship between tourists' receipts and GDP per capita. 


\section{Macrothink \\ International Journal of Accounting and Financial Reporting \\ ISSN 2162-3082 \\ 2020, Vol. 10, No. 4}

Table 2. Results of Correlation Analysis

\begin{tabular}{|c|c|c|}
\hline \multicolumn{3}{|c|}{$\begin{array}{l}\text { Covariance Analysis: Ordinary } \\
\text { Date: } 11 / 17 / 19 \text { Time: } 12: 19 \\
\text { Sample: } 19892018 \\
\text { Included observations: } 30 \\
\end{array}$} \\
\hline $\begin{array}{l}\text { Correlation } \\
\text { Probability }\end{array}$ & GDP PER. & TOURISTS. \\
\hline GDP PER CAPITA & 1.000000 & \\
\hline TOURISTS REC... & $\begin{array}{r}0.955684 \\
0.0000 \\
\end{array}$ & $\begin{array}{r}1.000000 \\
- \\
\end{array}$ \\
\hline
\end{tabular}

The results of correlation analysis are displayed in Table 2 . The findings reveal that there is positive correlation between tourism industry (tourists' receipts) and economic growth (GDP per capita) with the estimated coefficient value of 0.955684 and $p$ value of 0.0000 which is significant at 1 per cent significant level. Therefore, there is strong and positive relationship between tourism industry and economic growth. This finding is supported with previous studies (Lee\& Kwon.1995.)

\subsection{Results of Regression Analysis}

Regression analysis is carried out to examine how much of the variance in the dependent variable is predicted by the independent variable. Regression analysis is employed to measure the impact of tourism industry (tourists' receipts) on economic growth (GDP per capita).

Table 3. Results of Regression Analysis

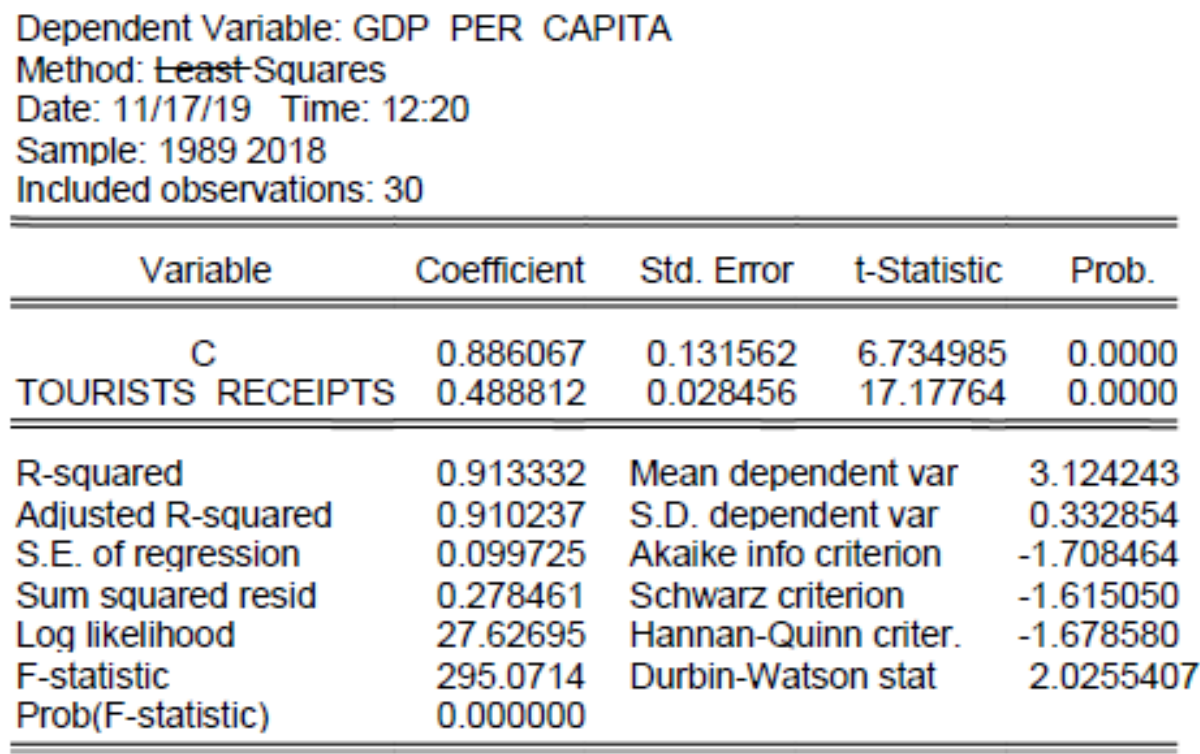

As shown in the Table 3, the R-squared is 0.913332 , the adjusted R-squared value is 0.910237 which endorses that nearly 92 per cent of the variation in the economic growth (GDP per capita) is explained by the independent variable, tourists receipts. $\mathrm{P}$ value of tourists receipts is 0.0000 


\section{MIMacrothink}

International Journal of Accounting and Financial Reporting

ISSN 2162-3082

2020, Vol. 10, No. 4

which is significant at 1 per cent significant level. Hence, it can be concluded that tourism industry significantly impacts on economic growth.

\subsection{Unit Root Test}

Unit root test is employed in this research study to examine whether a time series variable is stationary or non-stationary and possesses a unit root. The stationarity of the data is checked by using Augmented Dickey-Fuller (ADF) test.

Table 4. Results of Unit root test

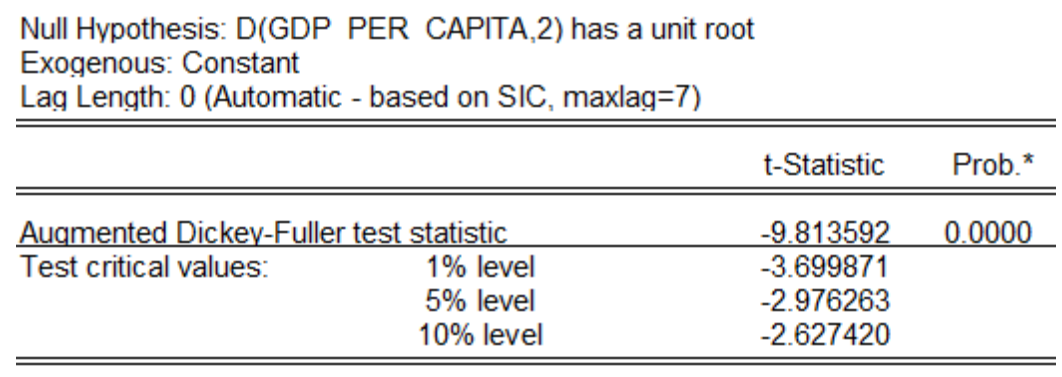

*MacKinnon (1996) one-sided p-values.

The ADF statistic value is -9.813592 and the associated one-sided p-value is 0.0000 . The statistic value here is greater than the critical values and $\mathrm{p}$ value is 0.0000 . Therefore, GDP per capita is stationary.

Null Hypothesis: D(TOURISTS RECEIPTS) has a unit root
\begin{tabular}{llll} 
Exogenous: Constant \\
Lag Length: 0 (Automatic - based on SIC, maxlag=7) & & \\
\hline \hline & t-Statistic & Prob. $^{*}$ \\
\hline \hline Auqmented Dickey-Fuller test statistic & -4.326760 & 0.0021 \\
\hline Test critical values: & $1 \%$ level & -3.689194 & \\
& $5 \%$ level & -2.971853 & \\
& $10 \%$ level & -2.625121 & \\
\hline \hline
\end{tabular}

*MacKinnon (1996) one-sided p-values.

The ADF statistic value is -7.535413 and the associated one-sided p-value is 0.0000 . Therefore, tourists receipts is stationary.

\subsection{Residuals Normality Test}

The residual normality analysis is employed in researches to prove the model fitness. 


\section{Macrothink Institute}

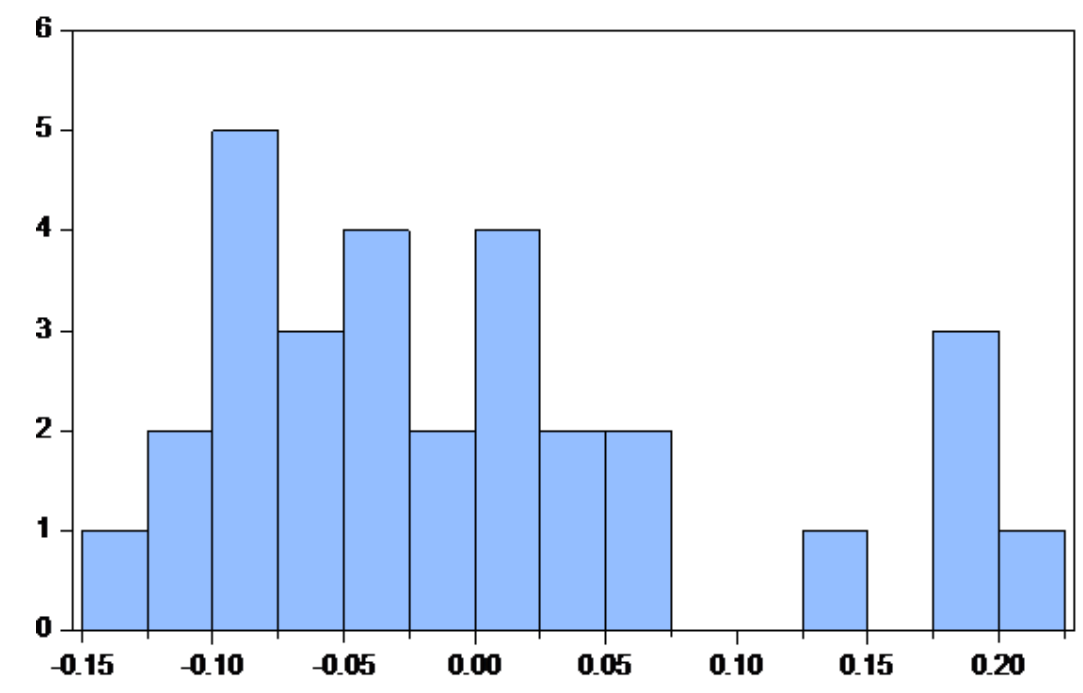

International Journal of Accounting and Financial Reporting

ISSN 2162-3082 2020, Vol. 10, No. 4

Figure 3. Histogram of the residuals Normality

The Jarque-Bera value is 3.774932 and $p$ value is 0.151455 . Therefore, it can be concluded that this model is fit enough.

\section{Conclusion}

Tourism industry has already featured as highest foreign exchange earning sector in Sri Lanka. Tourism and economic growth are conceptualized as an econometric model to evaluate the economic growth of Sri Lanka from 1989 to 2018. This study primarily investigated the impact of tourism on economic growth for the economy of Sri Lanka by employing Augmented Dickey Fuller's unit root test, correlation analysis, regression analysis, The correlation analysis shows a strong and positive correlation between tourists' receipts and economic growth meanwhile regression analysis indicates that tourists' receipts significantly impact on the economic growth. It has been proved that tourism industry accelerates the economic growth. Even tourists' arrivals dropped by 50 per cent after Easter attack in April 2019 and tourism industry lost about $\$ 750$ Million. Therefore, the government should ease the burden of the tourism industry by reducing the root causes of ethnic conflicts. Providing equal opportunities for all Sri Lankan would lead to peaceful environment in Sri Lanka. It will attract more tourists and bring more tourism revenue to the country.

\section{References}

Central Bank of Sri Lanka. (2018). Retrieved 8 November 2019, from https://www.cbsl.gov.lk/

David, C., Fulbright. F., Marinko, S., \& Jasmina, L. (2004). The impact of War on Tourism: The case of Croatia.

Ding, D., Alan, L., \& Pin, N. (2016). Tourism and Economic Growth. Journal of Travel Research, 55, 454-464. https://doi.org/10.1177/0047287514563167

Dritsakis, N. (2012). Tourism development and economic growth in seven Mediterranean countries: A panel data approach. Tourism Economics, 18(4), 801-816. 


\section{Macrothink}

International Journal of Accounting and Financial Reporting

ISSN 2162-3082 2020, Vol. 10, No. 4

Fayissa, B., Nsiah, C., \& Tadasse, B. (2007). The Impact of Tourism on Economic Growth and Development in Africa. Working Papers 200716, Middle Tennessee State University, Department of Economics and Finance.

Govdeli, T., \& Direkci, T. (2017). The relationship between tourism and economic growth: OECD countries. International Journal of Academic Research in Economics and Management Sciences, 6(4).

Khan, H., Phang, S., \& Toh, R. (1995). The multiplier effect: Singapore's hospitality industry. Cornell Hotel and Restaurant Administration Quarterly, 36, 64-69.

Lee, C., \& Kwon, K. (1995). Importance of secondary impact of foreign tourism receipts on the South Korean economy. Journal of Travel Research, 34, 50-54.

Saroja, S. (2007). The effect of war and other factors on Sri Lankan tourism. Applied Economics Letters, 14, 35-38. https://doi.org/10.1080/13504850500425576

SriLanka Tourism Development Authority. (2018). Retrieved 8 November 2019, from https://www.sltda.gov.lk/

UNWTO. (2006). Africa: A Key Resource for Economic and Social Development. Global Envision.

WTO. (2000). Yearbook of tourism statistics. World Tourism Organization, Madrid.

Yusuf, A., Cem, I., \& Ibrahim, A. (2009). The Impact of Tourism on Economic Growth: The Case of Turkey. Journal of Tourism, 9.

\section{Copyright Disclaimer}

Copyright for this article is retained by the author(s), with first publication rights granted to the journal.

This is an open-access article distributed under the terms and conditions of the Creative Commons Attribution license (http://creativecommons.org/licenses/by/4.0/) 